\title{
Partial special issue: Papers from the 2019 CLImate-Smart Forestry in MOuntain Regions (CLIMO) Workshop
}

\author{
Guest Editors \\ Milica Kašanin-Grubin, Institute of Chemistry, Technology, and Metallurgy, National Institute of the Republic of Serbia, \\ University of Belgrade, Belgrade, Serbia \\ Andrew Weatherall, National School of Forestry, University of Cumbria, Ambleside, Cumbria, England
}

